\title{
Spatial patterns of zooplanktivore Chirostoma species (Atherinopsidae) during water-level fluctuation in the shallow tropical Lake Chapala, Mexico: seasonal and interannual analysis
}

\author{
Rodrigo Moncayo-Estrada ${ }^{1}$, Carlos Escalera-Gallardo ${ }^{1}$ and Owen T. Lind ${ }^{2}$
}

This study addresses the influence of water-level fluctuations on fish distribution at two temporal scales: seasonal (dry and rainy) and interannual (low and high volume conditions). The analysis of abundance relationships among three zooplanktivore Chirostoma species at fifteen sites in Lake Chapala, Mexico, revealed the significant influence of contrasting conditions ( $\mathrm{P}=0.0002)$. Seasonally, segregation was more related to species dominance in the dry season and exclusively related to environmental characteristics in the rainy season. Interanually, biotic influence occurred in the shallowest and the deepest episodes of the lake. Environmental characteristics influenced species distribution when the lake reached $25 \%$ of its volume. Site, depth, temperature, and salinity were the leading factors influencing fish distribution. These results emphasize the necessity to implement different management strategies according to lake volume, particularly when a critical threshold is reached.

El presente estudio describe la influencia que tiene la fluctuación del nivel del agua en la distribución de los peces a dos diferentes escalas: estacional (estiaje y lluvias) e interanual (condiciones de bajo y alto volumen). El análisis de las relaciones de abundancia entre tres especies zooplanctófagas de Chirostoma en quince sitios del Lago de Chapala, México, reveló una influencia estadísticamente significativa en las condiciones contrastantes $(\mathrm{P}=0.0002)$. Estacionalmente, la segregación estuvo más relacionada a la dominancia de las especies en la época de estiaje y exclusivamente relacionada a las características ambientales en la época de lluvias. Interanualmente, la influencia biótica se presenta en los episodios más someros y más profundos del lago. Las características ambientales influenciaron la distribución de las especies cuando el lago alcanzó el 25\% de su volumen. El sitio geográfico, profundidad, temperatura y salinidad fueron los principales factores que influenciaron la distribución de los peces. Estos resultados enfatizan la necesidad de implementar diferentes estrategias de manejo de acuerdo al volumen del lago, particularmente cuando se alcanza un umbral crítico.

Key words: Dry season, Rainy season, Silversides, Temporal scale, Volume change.

\section{Introduction}

Water-level fluctuations are the decisive element of hydrology especially in shallow lakes, and may have an overriding effect on the biota's ecology, functioning and management (Coops et al., 2003). Water-levels in shallow lakes naturally fluctuate intra- and interannually depending largely on regional climatic conditions (e.g. temperate, semi-arid and, arid) and human activities (Blindow, 1992). In shallow lakes, especially those of large area, a change in depth affects different environmental characteristics such as turbidity, salinity, and temperature (Rossier, 1995; Fischer \& Eckmann, 1997). In some cases these factors may vary three fold among seasons (Fukuhara et al., 2003).

Multiscale distribution patterns of fish, within environmental fluctuations events, have been described in relation to various aspects: local processes and regional patterns (Olden \& Jackson, 2001), habitat heterogeneity (Hargeby et al., 2004; Fischer \& Öhl, 2005), environmental gradients (Tejerina-Garro et al., 1998; Brind'amour et al., 2005), and habitat alteration processes (Welker \& Scarnecchia, 2006). However, very few studies have simultaneously evaluated

${ }^{1}$ Centro Interdisciplinario de Investigación para el Desarrollo Integral Regional, Instituto Politécnico Nacional, Unidad Michoacán, Justo Sierra \#28 Jiquilpan, Michoacán 59510, México.rmoncayo@hotmail.com; cescalera@ipn.mx

${ }^{2}$ Laboratory of Limnology, Biology Department, Baylor University. One Bear Place \#97388, Waco, Texas 76798-7388, USA. Owen_Lind@baylor.edu 
the relationship between fish distribution and environmental variables at different temporal scales, including contrasting habitat characteristics (Hayes et al., 1992; Connell \& Kingsford, 1998; Meryem et al., 2007). This information is critical for the development of effective conservation efforts and management policies. Consequently, the goal of the present work was to analyze the spatial patterns of closely related species, according to physical and chemical characteristics, at different seasons and years within a waterlevel fluctuation event.

Lake Chapala was selected for this study because it had an important volume change - a major loss of volume and a subsequent recovery (in millions of cubic meters: 2,839 in $1999 ; 2,147$ in 2000; 1,820 in 2001 with a recovery to 5,286 in 2005) (CNA, 2006). In addition, this lake has the most important adaptive radiation of atherinopsids in fresh water: The Chirostoma flock consisting of eight species (Barbour, 1973; Barbour \& Chernoff, 1984). We selected three species for the analysis - Chirostoma jordani, C. consocium, and C. labarcae - because they are the dominant species within the flock, they belong to the same guild (zooplanktivores), and they are the objective species of the local "charales" fishery (Moncayo-Estrada \& Buelna-Osben, 2001; Moncayo-Estrada et al., 2011). Thus, these were expected to have strong population interactions related to the water fluctuations.

In this study, we used constrained ordination to describe the influence of five selected environmental variables, that better described the lake characteristics, and interspecific relationships on the distribution of the three fish. We asked three questions: (1) Is there a significant difference in the species spatial patterns in contrasting conditions (low and high volume levels)? (2) What aspects, biological relations and/or environmental influence, define the species distribution at the seasonal scale? (3) Is it possible to identify a critical volume, between contrasting conditions, when environmental characteristics have an important effect on fish distribution? Answers to these questions will allow the exploration of how heterogeneity in environmental characteristics may influence fish persistence in shallow lakes. Additionally, they could help to elaborate management strategies using easily measurable variables.

\section{Material and Methods}

\section{Study Area}

Lake Chapala, Mexico $\left(20^{\circ} 21^{\prime} 18^{\prime \prime} \mathrm{N} 103^{\circ} 26^{\prime} 30^{\prime \prime} \mathrm{W}\right)$, is a large, shallow and turbid lake. With a relative depth of $0.02 \%$, this lake is one of the largest shallow lakes in the world (Lind \& Dávalos-Lind, 2002). It is an ancient tropical lake with a regular ellipsoid shape that measures an average $75 \mathrm{~km}$ long and $24.8 \mathrm{~km}$ wide. According to biophysical characteristics, Lake Chapala is defined as neotectonic and oligotrophic (Lind \& Dávalos-Lind, 1991). The lake has not been at capacity (7,897 millions of cubic meters) since 1974, with a continuous decline in volume interrupted with periods of partial volume recovery (relationship among volume and depth was established by the Secretary of Hydraulic Resources according to a locally defined benchmark where $1,523.80 \mathrm{~m}$ above sea level is defined as the maximum capacity and $8 \mathrm{~m}$ average depth). One low period occurred in 2001 ( $20 \%$ of the total lake volume, $1.5 \mathrm{~m}$ average depth and $2 \mathrm{~m}$ maximum depth) and a strong recovery episode occurred in 2005 (67\% of the total lake volume, $4.1 \mathrm{~m}$ average depth and $8 \mathrm{~m}$ maximum depth) (CNA, 2006). Lake Chapala is influenced by a well-defined rainy season, from June to October, and a dry season during the rest of the year (Lind \& Dávalos-Lind, 1991).

\section{Sampling procedure}

The study covers a total of four years: three times during low volume conditions (1999 to 2001) and once time during high volume conditions (2005). Fish abundance and environmental variables were quantified over 15 sites that systematically covered the lake (Fig. 1). The sampling design was defined as a net of sites separated approximately ten kilometers from each other. This net was located in such a way to cover different habitat characteristics (rivers inflow and outflow, different depth and bottom type, littoral and limnetic zones). Each site was located by a global positioning system (Garmin-GPS 12) with a precision of $6 \mathrm{~m}$. The sites were surveyed seasonally every year, in the peaks of the dry (May) and the rainy (August) seasons (30 fish samples each year but 2001 when five sites, mainly related to the south shore of the lake, dried up in the dry season).

Five environmental variables were measured immediately before the fish collections at each site using a Hydrolab DataSonde 4X (Hach Company). These variables were selected because they better described the limnological characteristics of the lake at different years (Chávez,1973; U de G, 1983; Guzman, 1995, 2002; Lind \& Davalos-Lind, 2002): water depth (m), turbidity (NTU), temperature $\left({ }^{\circ} \mathrm{C}\right)$, dissolved oxygen $\left(\mathrm{mg} \cdot \mathrm{l}^{-1}\right)$, salinity (ppt), conductivity, and $\mathrm{pH}$. According to the limnetic distribution of the zooplantivores Chirostoma species (Moncayo-Estrada \& Buelna-Osben, 2001), fish were sampled with a mid-water net $(50 \mathrm{~m} \times 2 \mathrm{~m})$ trawled by boat for $15 \mathrm{~min}$ per site. Individuals of Chirostoma jordani, C. labarcae, and $C$. consocium were selected and preserved with $10 \%$ buffered formaldehyde. The identity of the fish was corroborated at the laboratory using biometric parameters, with the help of Barbour's (1973) identification keys, and other life strategies were considered for discussion (Table 1). Specimens were

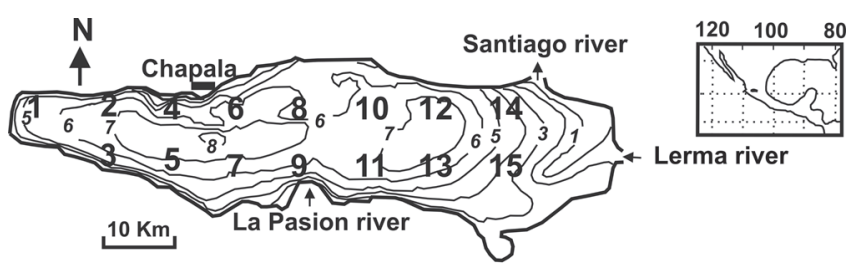

Fig. 1. Map of Lake Chapala, Mexico. Numbers in bold represent sample sites and numbers in italic lake depths. 
Table 1. Chirostoma species biometrics and life strategies characteristics. Abbreviations are: Chirostoma jordani (jor), $C$. labarcae (lab) C. consocium (con) weight (W; average, maximum-minimum), standard length (SL; average, maximum-minimum), jaw length (Jaw; average, maximum-minimum) and March (Mar; sample sites). Number of individuals of copepods and cladocerans found on the diet. Tolerance: Tolerant $(\mathrm{T})$ and medium tolerance $(\mathrm{M})$.

\begin{tabular}{|c|c|c|c|c|c|c|c|}
\hline Species & W $(g)$ & $\mathrm{SL}(\mathrm{cm})$ & Jaw $(\mathrm{cm})$ & Copepod & Cladocera & Tolerance & Reproduction \\
\hline jor & $1.9(0.4-3.3)$ & $5.4(3.5-6.6)$ & $0.4(0.3-0.6)$ & 832 & 6032 & $\mathrm{~T}$ & Mar-May $(4,5,15)$ \\
\hline lab & $3.8(0.1-10.9$ & $6.5(2.2-9.0)$ & $0.7(0.2-0.9)$ & 8 & 11520 & M & May $(5,8)$ \\
\hline con & $2.6(0.2-10)$ & $5.8(2.8-10)$ & $0.5(0.3-1.0)$ & 992 & 3120 & M & $\operatorname{Mar}(4,5,8)$ \\
\hline
\end{tabular}

incorporated to the fish collection at the Universidad Michoacana de San Nicolas de Hidalgo in Mexico (CPUM, registration key: MICH.-PEC-227-07-09). Catalog numbers: Chirostomajordani, CPUM 5000, 5003, 5006, 5009, 5012, 5015, $5018,5021,5024,5027,5030,5033,5036,5039,5042$ for year 2000 and CPUM 5045, 5048 for year 2005; C. labarcae, CPUM 5001, 5004, 5007, 5010, 5013, 5016, 5019, 5022, 5025, 5028, 5031, 5034, 5037, 5040, 5043 for year 2000 and CPUM 5046, 5049 for year 2005; C. consocium, CPUM 5002, 5005, 5008, 5011, 5014, $5017,5020,5023,5026,5029,5032,5035,5038,5041,5044$ for year 2000 and CPUM 5047, 5050 for year 2005.

\section{Data analyses}

To test the hypothesis that there were no distribution differences between contrasting environmental conditions, we only used years 1999/2000 (low lake volume) and 2005 (high lake volume). We excluded 2001 because of the lack of information in five sites which dried up that year. Distancebased permutational multi-variate analysis of variance (PERMANOVA - Anderson, 2001) was employed in a twoway factorial design to test for differences among years and between seasons. Bray-Curtis dissimilarities were used for this test due to the frequency of zeros in the data set (McCune et al., 2000). Differences among years were considered significant at a $P$-level $<0.016$ (Bonferroni's correction: $\alpha=0.05 / 3$ comparisons). The statistical significance of multivariate variance components were tested using 4,999 unrestricted permutations of raw data using correct permutable units (Anderson, 2001). PERMANOVA was performed using PC-ORD version 5.07 (McCune \& Mefford, 2006).

We used generalized additive models (GAM) to characterize the seasonal trend of environmental effects and biological relations on fish distribution. The abundance data from those years within low volume conditions (1999 to 2001) were joined to run this analysis. For considering species interactions, we set up GAM models where each modeled species was incorporated as a predictor into the model of another species (Brzeziecki, 1987). Variation partitioning with a different explanatory set of variables was established: (i) pure effect of environmental characteristics, (ii) pure effect of species dominance and (iii) the two groups of explanatory variables. GAM is a non-parametric regression method where least squares fits in linear regression are replaced by smoothes using local smoothers (Hastie \& Tibshirani, 1990). We used the Gaussian distribution for the models, as well as the locally weighted smoother of Cleveland (1979), currently designed by "lowess". Results from the GAM models are displayed as a set of effects plots. Each plot shows the best fitting smooth and 95\% confident limits (strictly Bayesian credible intervals) for the effect of a covariate on the parameter of interest (Wood, 2006). GAM models were set up using the 'gam' package in the freeware $\mathrm{R}$ (version 2.5.1) (Hastie, 1992).

We used the distance-based redundancy analysis (dbRDA) (Legendre \& Anderson, 1999) to identify the critical volume threshold that results from multivariate interactions between the species spatial patterns and environmental characteristics. We analyzed dry and rainy seasons, including all years, in the low and high volume conditions of the lake. This analysis was selected because a detrended correspondence analysis, not presented here, showed species turnover $<2$ SD units, which is the recommended criterion for choosing linear versus uni-modal ordination models (Lepš \& Šmilauer, 2003). Bray-Curtis distant measure was used as this is reasonable for ecological data sets (McArdle \& Anderson, 2001). The db-RDA was carried out on the correlation matrix and forward selection procedure was used to determine significant explanatory variables $(\mathrm{P}=0.05)$ (Magalhães et al., 2002). Statistical significance was determined by Monte-Carlo tests using 499 permutations. Abundance values were transformed logarithmically and those environmental variables that failed normality were transformed using square root transformation. CANOCO 4.5 computer program was used to run db-RDA (ter Braak \& Šmilauer, 2002).

\section{Results}

\section{Environmental variability}

Seasons and years differed significantly in environmental characteristics, particularly in the lowest and highest volume conditions (Table 2). Depth of high volume conditions - year 2005 - was around three times greater than low volume conditions - year 2001 - in both seasons. Turbidity was two magnitude orders greater in low volume than high volume conditions, but year 1999, and varied mainly in the high volume regime. There was a slight but non-significant tendency for surface water temperature to be higher during warmer recovery years. In general, mean dissolved oxygen was greater in high volume conditions than in low volume. Salinity, conductivity, and $\mathrm{pH}$ increased in both seasons within low volume conditions of the lake (Table 2). 
Table 2. Environmental variables mean values in Lake Chapala at different years.

\begin{tabular}{cccccccc}
\hline & Depth (m) & Turbidity (NTU) & Temperature $\left({ }^{\circ} \mathrm{C}\right)$ & $\begin{array}{c}\text { Dissolved Oxygen } \\
\left(\mathrm{mg} \cdot \mathrm{L}^{-1}\right)\end{array}$ & $\begin{array}{c}\text { Conductivity }\left(\mu \mathrm{S} \cdot \mathrm{cm}^{-1}\right) \\
\mathrm{pH}\end{array}$ & Salinity $(\mathrm{ppt})$ \\
\hline May-99 & 1.8 & 104.7 & 23.2 & 5.7 & 1076.9 & 9.3 \\
May-00 & 1.5 & 141.6 & 24.8 & 6.8 & 1163.4 & 0.57 \\
May-01 & 0.8 & 147.1 & 23.8 & 4.6 & 1626.0 & 8.4 \\
May-05 & 3.8 & 55.1 & 25.7 & 8.6 & 748.9 & 0.59 \\
Aug-99 & 1.8 & 92.4 & 24.3 & 5.7 & 986.5 & 7.2 \\
Aug-00 & 1.5 & 129.5 & 22.5 & 6.3 & 1064.9 & 0.86 \\
Aug-01 & 1.1 & 142.7 & 24.4 & 6.4 & 1175.6 & 8.6 \\
Aug-05 & 5.0 & 34.7 & 24.7 & 7.8 & 653.1 & 0.5 \\
\hline
\end{tabular}

\section{Spatial distribution variability}

A total of 21,239 fish belonging to the three target species were captured during our study. Including all years, $58 \%$ were captured in August whereas 42\% were captured in May. Chirostoma jordani represented $61 \%$ of the total number captured, C. consocium 34\%, and C. labarcae 5\%. A significant difference in the Chirostoma species distribution, when comparing years of contrasting conditions (low and high volume), was supported by our PERMANOVA results $(\mathrm{P}=0.0002)$. Meanwhile, in the comparison between seasons and the interaction between years and seasons, there were not significant differences (Table 3). A posteriori pairwise tests of dispersion among years showed that two of the three possible pairwise were significantly different. The three species abundance at different sites was similar in years 1999 and $2000(\mathrm{t}=1.14, \mathrm{P}=0.27)$, but these years differed from year $2005(\mathrm{t}=3.70, \mathrm{P}=0.0002$ and $\mathrm{t}=5.56, \mathrm{P}=0.0002$, respectively $)$.

\section{Environmental and biological effects at seasonal scale in low volume conditions}

Different environmental variables from our exploratory GAM were significantly related to each of the three Chirostoma species in the dry season (May) (Table 4). Chirostoma jordani was correlated with depth, particularly in shallow conditions $(<1 \mathrm{~m})$, and with temperature, in the middle values of the range $\left(23.5\right.$ to $\left.25^{\circ} \mathrm{C}\right)$ (Fig. 2). Both environmental variables accounted for $30.6 \%$ and $16.6 \%$ of the total deviance, respectively. Chirostoma labarcae was related to the variable 'site', with a preferential distribution in the middle of the lake. Chirostoma consocium was mostly present at higher values of salinity $(0.55$ to $0.8 \mathrm{ppt})$ and this

Table 3. Permutational multivariate analysis of variance (PERMANOVA) on the basis of Bray-Curtis dissimilarities for the distribution of three species of Chirostoma in the Lake Chapala in three years $(1999,2000$, and 2005) and two seasons per year (rainy and dry).

\begin{tabular}{lccccc}
\hline Source & d.f. & SS & MS & F & P \\
\hline Years & 2 & 0.46145 & 0.23072 & 14.217 & 0.0002 \\
Seasons & 1 & $4.68 \mathrm{E}-02$ & $4.68 \mathrm{E}-02$ & 2.8816 & 0.0606 \\
Interac. & 2 & $5.69 \mathrm{E}-02$ & $2.84 \mathrm{E}-02$ & 1.7528 & 0.1446 \\
Residual & 84 & 1.3632 & $1.62 \mathrm{E}-02$ & & \\
Total & 89 & 1.9283 & & & \\
\hline
\end{tabular}

variable accounted for $31.3 \%$ of the total deviance (Fig. 2). In the rainy season (August), the variable 'site' was significantly correlated with two species showing a differential distribution: Chirostoma jordani was mainly found in the shallow eastern and western ends and C. consocium occupied the deeper central zone of the lake (Fig. 3). The last species was also highly correlated with temperature (values close to $22.5^{\circ} \mathrm{C}$ ). A correlation among species only occurred in the dry season. Chirostoma jordani was positively related to C. consocium (high abundance values of both species) in the lake's western end and $C$. jordani was negatively related to $C$. labarcae (low abundance values of $C$. labarcae when $C$. jordani was dominant). Chirostoma labarcae was also positively related to C. consocium but in the middle of the lake (Fig. 4). When combining the two groups of variables only two relations persisted. In the dry season the positive correlation between Chirostoma jordani and C. consocium. In the rainy season the relation between $C$. jordani and 'site' with the preferential distribution in both ends of the lake.

\section{Environmental effects on species abundance at seasonal and annual scale}

The forward selection procedure in db-RDA in the dry season revealed the presence of a significant effect of depth on species distribution in $1999(\mathrm{P}<0.02)$ (lake volume of 2,291 millions of cubic meters). This variable contributed to the observed significant association between fish species and environmental characteristics (Monte-Carlo test; $\mathrm{P}<0.002$ ). The first two dbRDA axes in the dry season accounted for a large proportion of variability in species-environment relations $(98.9 \%)$ and represented $80.6 \%$ of the variation in species data (Table 5). The ordination diagram defined by the first two dbRDA axes mainly reflected in the first axis a depth gradient (Fig. 5a). Distribution of site scores in this ordination space reflected a clear break between shallow and deep zones of the lake, associated with differential abundance of the species.

In the rainy season, the forward selection in db-RDA revealed in 1999 the presence of an effect of salinity and in 2000 of temperature on assemblage variation $(\mathrm{P}=0.048$ and $\mathrm{P}$ $<0.04$, respectively) (lake volume in millions of cubic meters of 2,839 in August 1999 and 2,147 in August 2000). The observed association between fish species and environmental characteristics was significant (Monte-Carlo test; $\mathrm{P}<0.004$ in 1999 and $\mathrm{P}<0.02$ in 2000). The first two db-RDA axes 
Table 4. Results of General Additive Modeling (GAM) analysis of the effects of (i) the environmental characteristics, (ii) the species abundance and (iii) the combination of the two groups on the zooplanktovorous Chirostoma species at seasonal scale in three years $\left(1999,2000\right.$, and 2001). Abbreviations are: Depth (m), turbidity (NTU; Turb), temperature $\left({ }^{\circ} \mathrm{C}\right.$; Temp), dissolved oxygen (mg• $\left.\mathrm{L}^{-1}, \mathrm{DO}\right)$, salinity (ppt, Sal), Chirostoma jordani (jor), C. labarcae (lab), and C. consocium (con). Shown are the probability values for the full GAM model for each variable. Significant codes: $* * 0.01, * 0.05$.

\begin{tabular}{|c|c|c|c|c|c|c|c|c|c|c|}
\hline \multicolumn{6}{|c|}{ (i) Habitat } & \multicolumn{5}{|c|}{ (ii) Species } \\
\hline Season & species & site & depth & Turb & Temp & DO & Sal & jor & lab & con \\
\hline \multirow{3}{*}{ Dry } & jor & 0.32 & $0.04 *$ & 0.09 & $0.04 *$ & 0.09 & 0.72 & - & 0.51 & 0.44 \\
\hline & lab & $0.02 *$ & 0.48 & 0.41 & 0.13 & 0.40 & 0.36 & $0.03 *$ & - & 0.06 \\
\hline & con & 0.26 & 0.53 & 0.18 & 0.24 & 0.13 & $0.03 *$ & $0.009 * *$ & $0.01 *$ & - \\
\hline \multirow{3}{*}{ Rainy } & jor & $0.006^{* *}$ & 0.22 & 0.60 & 0.42 & 0.96 & 0.26 & - & 0.22 & 0.06 \\
\hline & lab & 0.12 & 0.65 & 0.60 & 0.33 & 0.93 & 0.52 & 0.07 & - & 0.08 \\
\hline & con & $0.01 *$ & 0.14 & 0.47 & $0.009 * *$ & 0.13 & 0.08 & 0.10 & 0.89 & - \\
\hline \multicolumn{11}{|c|}{ (iii) Both groups combined } \\
\hline Season & species & jor & lab & con & site & depth & Turb & Temp & DO & Sal \\
\hline \multirow{3}{*}{ Dry } & jor & - & 0.68 & 0.93 & 0.64 & 0.23 & 0.33 & 0.15 & 0.37 & 0.86 \\
\hline & lab & 0.59 & - & 0.45 & 0.19 & 0.64 & 0.49 & 0.75 & 0.87 & 0.70 \\
\hline & con & $0.03 *$ & 0.36 & - & 0.49 & 0.45 & 0.23 & 0.66 & 0.26 & 0.07 \\
\hline \multirow{3}{*}{ Rainy } & jor & - & 0.40 & 0.25 & $0.03 *$ & 0.81 & 0.57 & 0.63 & 0.98 & 0.87 \\
\hline & lab & 0.55 & - & 0.13 & 0.55 & 0.17 & 0.75 & 0.36 & 0.52 & 0.59 \\
\hline & con & 0.85 & 0.47 & - & 0.07 & 0.37 & 0.79 & 0.08 & 0.27 & 0.29 \\
\hline
\end{tabular}

accounted in 1999 and 2000 with the same value for a large proportion of variability in the species-environment relations (93.4\%) and represented $64.3 \%$ and $59.5 \%$ of the variation in species data respectively (Table 5). The 1999 rainy season ordination diagram showed salinity and depth gradients related to the first and second axes respectively (Fig. 5b). The influence of depth and temperature was reflected better by both axes in 2000. Particularly, the shallowest sites 1 and 4 are related with the temperature vector (Fig. 5c).

\section{Discussion}

Results from the present study show that volume change in the shallow Lake Chapala - a critical low volume and a recovery period - could modify the distribution patterns of three closely related species of Chirostoma. This conclusion leads to the necessity of implementing different management strategies according to volume level. The methods used to evaluate the different temporal scales helped to identify that species segregation was more affected by the correlation among species dominances in the dry seasons and year 2001 - when the lake reached a critical low volume. On the other hand, the analysis of the rainy season and recovery conditions of the lake showed a high correlation with site and the environmental factors analyzed. Depth, salinity, and temperature were the pertinent environmental variables that most accurately described fish spatial patterns.

In general, in the spatial dimension, species distribution patterns divide Lake Chapala into three zones: eastern, central, and western zones. A similar arrangement had been described
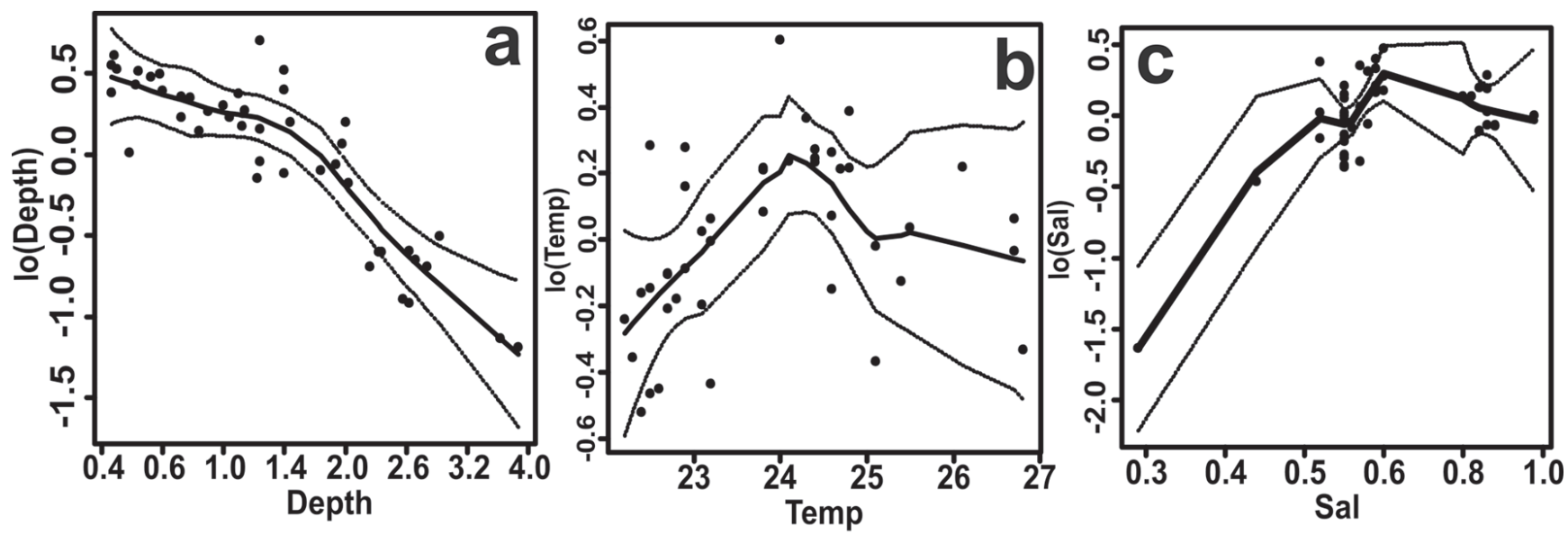

Fig. 2. GAM results for May of environmental characteristics influence on fish density. a: effect of depth (m) on Chirostoma jordani; b: effect of temperature $\left({ }^{\circ} \mathrm{C}\right)$ on C. jordani; $\mathbf{c}$ : effect of salinity on C. consocium. Circles represent the residuals. Spline fit (solid line) is bound by $95 \%$ confidence intervals (dotted lines). 

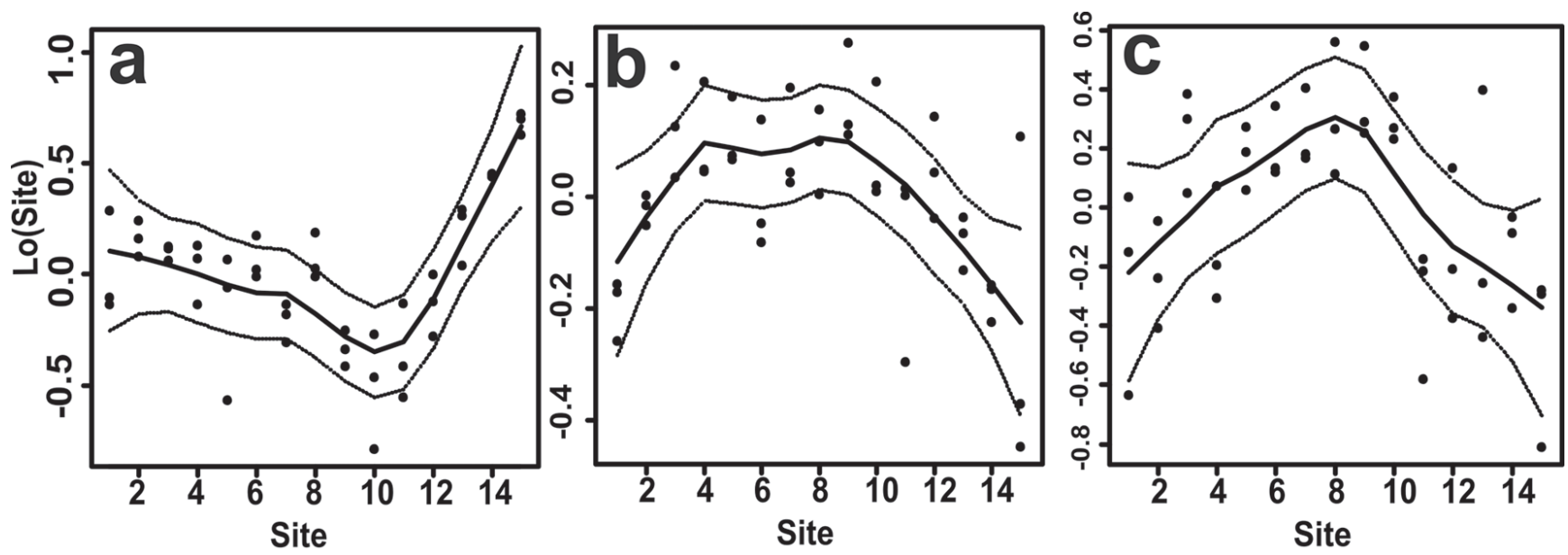

Fig. 3. GAM results for May and August of site influence on fish density to show differential distribution of species in Lake Chapala. a: Chirostoma jordani; b: Chirostoma consocium; c: Chirostoma labarcae. Circles represent the residuals. Spline fit (solid line) is bound by $95 \%$ confidence intervals (dotted lines).

before in Lake Chapala from the study of physical (turbidity and secchi depth) and biological characteristics (phytoplankton production and Chlorophyll a concentration), defining a distinct spatial (east-west) gradient (Lind \& Dávalos-Lind, 1991). In the temporal dimension, in low volume conditions, fish abundance varied only in a few sites between seasons in the same year (PERMANOVA, $\mathrm{P}$ $=0.06)($ Table, 3$)$. The only exception to this pattern was year 2001 when Chirostoma jordani dominated in most sites and this could be related to species' small size and fast growing and long maximum reproduction cycle (Table 1). However, abundance changed greatly in recovery conditions (2005) and Chirostoma consocium overcome the C. jordani dominance in the western region an aspect that explains the significant difference among years (Table 3 ). Such change could be related to the recovery of food arenas and reproductive grounds (Table 1). Water-level fluctuations in shallow lakes may dramatically change the dominant pattern of fish and, in low volume periods, tolerant species generally overcome other species (Lévêque, 1997). From the three species, Chirostoma jordani is the most tolerant and widely distributed species (Lyons et al., 2000), aspects that explain the change in dominance in contrasting periods of the lake (Table 1).

The strong relationship between fish abundance and the bathymetric profile of the lake, identified water depth as an important factor linked to fish distribution. In temperate lakes this relationship is better established in vertical stratums where
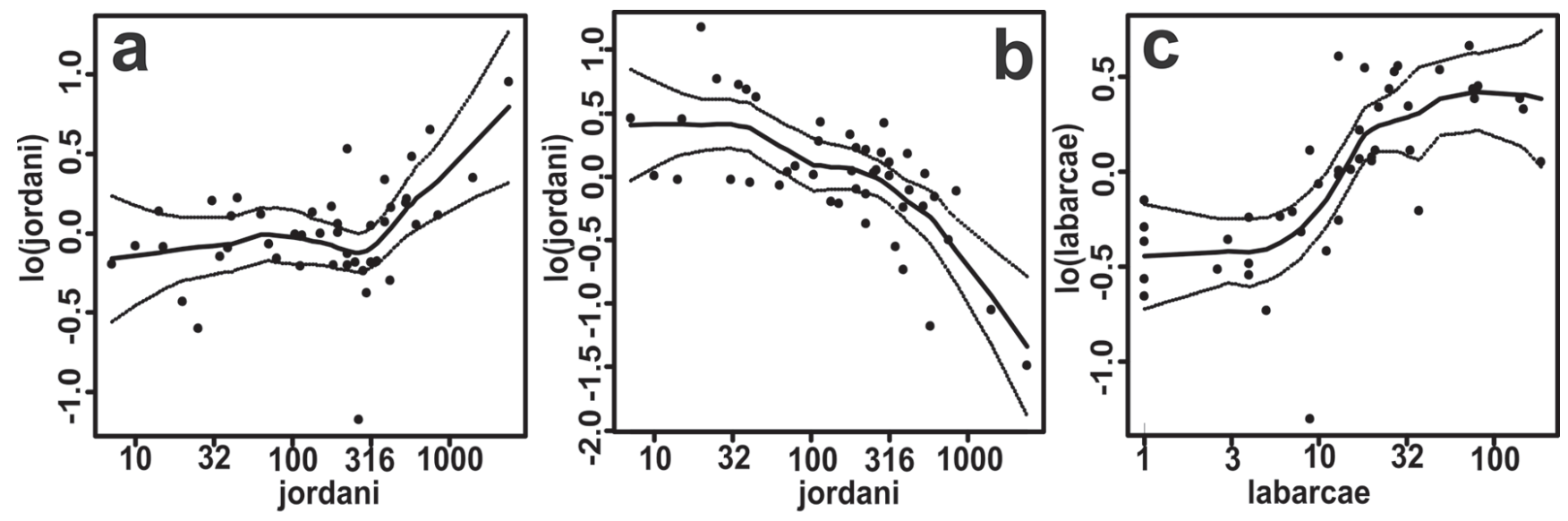

Fig. 4. GAM results for May of species correlation influence on fish density. a: effect of Chirostoma jordani on C. consocium; b: effect of $C$. jordani on $C$. labarcae; c: effect of $C$. labarcae on $C$. consocium. Circles represent the residuals. Spline fit (solid line) is bound by $95 \%$ confidence intervals (dotted lines). 

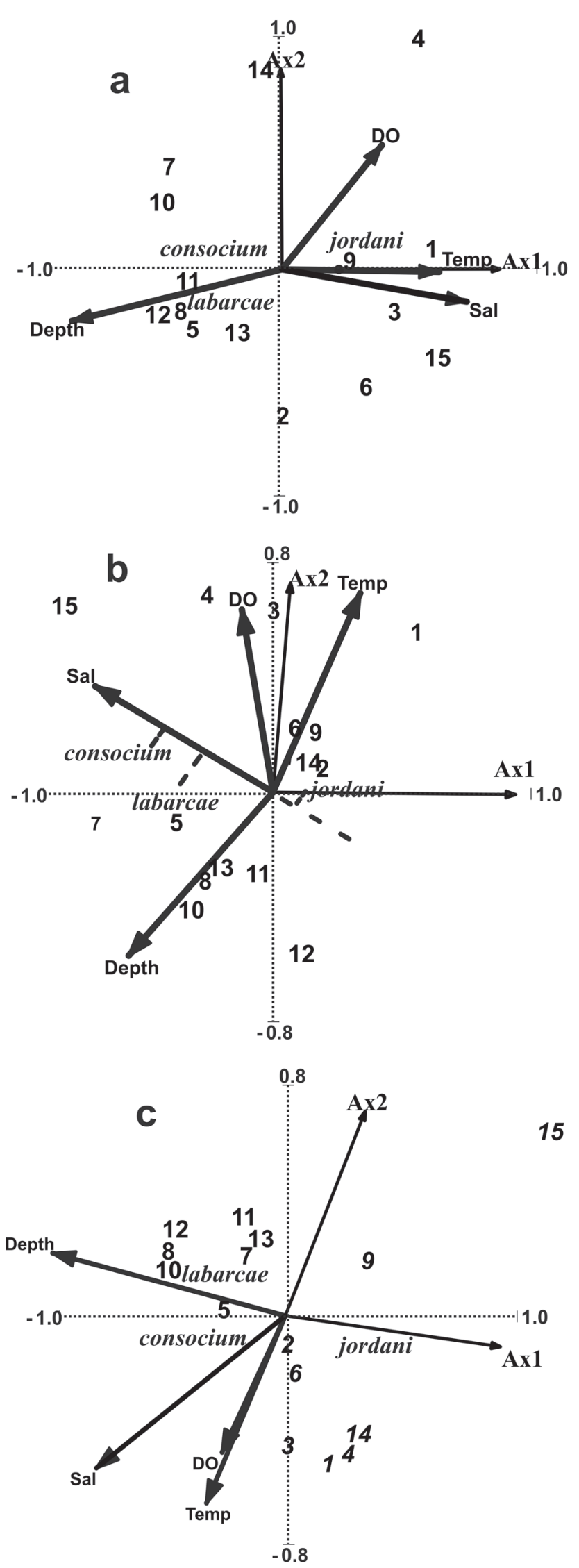

surface waters, mainly related to the littoral and limnetic zones, offer different conditions than the deeper stratum (Hamrix, 1986; Brosse et al., 1999). However, in the case of large shallow lakes and particularly in low volume conditions, the differentiation is only related to littoral and limnetic zones. This occurs because a constant mixture of the full water column, associated with Langmuir supercells (Gargett et al., 2004), vertically homogenize the environmental characteristics (Lind \& Dávalos-Lind, 1991). In dry and rainy seasons, species tended to keep segregated by choosing zones with different depths: Chirostoma jordani occupied the eastern and western shallow littoral zones, and C. labarcae and C. consocium preferentially distributed into central deep limnetic areas (Figs. $2 \mathrm{a}, 3$ ). This pattern was also graphically represented in the ordination analysis when depth was the most important variable correlated to the differential distribution of all species (May 1999, F = 1.63; P<0.018) (Fig. 5a). Similarly, in tropical floodplain lakes the structure of the fish assemblage was predictably related mainly to depth and transparency (Tejerina-Garro et al., 1998; Pouilly \& Rodríguez, 2004).

A preferential distribution from Chirostoma species to areas with higher salinity has been related to the marine origin of these fish (Barbour, 1973). Although there is a differential distribution of the three species in a salinity gradient, this is not necessarily related to a tolerant response. The salinity values of Lake Chapala are smaller than those from other Central Mexico lakes (i.e. Lake Cuitzeo), where Chirostoma jordani is distributed preferentially in places with high salinity (8.0 ppt) (Martínez-Pantoja et al., 2001). In the ordination analysis of August 1999 this factor was also related to fish distribution $(\mathrm{F}=1.7 ; \mathrm{P}<0.048)$. When projecting the species point to the axis of salinity in the db-RDA (Fig. 5b), the results showed that Chirostoma consocium was mainly found in sites with higher salinity than C. jordani. In years 1999 and 2000 when Lake Chapala has an intermediate volume level between low and high volume conditions, two aspects might be related to significant effect from the environmental variables on fish distribution patterns. First, a more relaxed species interaction and, second, a stronger spatially structured habitat. The reason that two different seasons in subsequent years showed an influence from the environmental characteristics is related to the similar volume level in both $\left(2,219 \mathrm{~mm}^{3}\right.$ in average). Such value represents the $25 \%$ volume of the lake and provides a

Fig. 5. (left column) Distribution-based Redundancy Analysis (db-RDA) ordination diagram of Lake Chapala with environmental variables (thick arrows), atherinopsids species (italic letters), sampling sites (numbers), and principal coordinates axes (thin arrows) at dry season (a: May of 1999) and rainy season (b: August of 1999; c: 2000). The fish are: jordani $=$ Chirostoma jordani , consocium $=$ Chirostoma consocium; labarcae $=$ Chirostoma labarcae. The environmental variables are: $\mathrm{Temp}=$ temperature, $\mathrm{DO}=$ dissolved oxygen, $\mathrm{Sal}=$ salinity. In figure $5 \mathrm{c}$ shallow sites are in italic and deep sites in regular. 
Table 5. Results of distance-based Redundancy Analysis (dbRDA) quantifying the statistical association between fish spatial patterns and environmental variables in the Lake Chapala.

\begin{tabular}{|c|c|c|c|c|c|c|c|c|c|}
\hline \multirow[t]{2}{*}{ Statistics } & \multicolumn{3}{|c|}{ dbRDA axis 1} & \multicolumn{3}{|c|}{ dbRDA axis 2} & \multicolumn{3}{|c|}{ dbRDA axis 3} \\
\hline & May99 & Aug99 & Aug00 & May99 & Aug99 & Aug00 & May99 & Aug99 & Aug00 \\
\hline Correlations of environmental variables with ordination axis & & & & & & & & & \\
\hline Depth & -0.91 & -0.51 & -0.90 & -0.23 & -0.58 & 0.24 & -0.09 & 0.14 & -0.02 \\
\hline Salinity & 0.80 & -0.63 & -0.73 & -0.14 & 0.38 & -0.59 & -0.56 & 0.11 & -0.21 \\
\hline Temperature & 0.68 & 0.31 & -0.30 & -0.01 & 0.71 & -0.72 & -0.64 & -0.27 & 0.06 \\
\hline Summary statistics for ordination axis & & & & & & & & & \\
\hline Eigenvalues: & 0.76 & 0.56 & 0.40 & 0.05 & 0.09 & 0.19 & 0.01 & 0.03 & 0.03 \\
\hline Species-environment correlations: & 0.95 & 0.87 & 0.88 & 0.90 & 0.77 & 0.88 & 0.46 & 0.72 & 0.58 \\
\hline $\begin{array}{l}\text { Cumulative percentage variance } \\
\text { of species data: }\end{array}$ & 75.5 & 55.8 & 40.3 & 80.6 & 64.3 & 59.5 & 81.1 & 66.8 & 62.9 \\
\hline of species-environment relation: & 92.6 & 81 & 63.3 & 98.9 & 93.4 & 93.4 & 99.4 & 96.9 & 98.7 \\
\hline
\end{tabular}

probable critical level when the environmental variables affect more the fish distribution.

The importance of species interactions in structuring communities compared with abiotic factors has been described in littoral portions of lakes (Hinch et al., 1991; Brind'Amour et al., 2005). In Lake Chapala, the continuously high abundance values and spatial dominance of Chirostoma jordani and $C$. consocium, compared with $C$. labarcae, suggests a major influence by biotic rather than abiotic factors on distribution. This influence varies at different temporal scales: on the seasonal scale the species dominance affected the spatial patterns more in low volume conditions (dry) and could be related to reproductive peaks (March to May) (Table 1). On the interannual scale, species dominance influenced fish distribution only during low volume critical conditions (2001) and the recovery of Lake Chapala (2005). In the case of the low volume conditions, this aspect could be related to more forced species interactions as a change in population density due to change in water volume ('concentration' effect) (Blake, 1977; Ita, 1978). The influence of biotic relationships in recovery conditions could be related to the increasing transparency of a deeper lake that affects prey distribution (Castro et al., 2007), the development of feeding arenas where species tend to coincide according to similar diets (Walters \& Martell, 2004) (Table 1).

The analysis of two seasons in four years within contrasting environmental conditions, provided a general preliminary insight into the effects of scale on differential distribution of closely related fish. The present study shows that the distribution of the three target species of Chirostoma is ruled by a combination of several abiotic-biotic variables acting mainly in a nonlinear way. These complex responses had been related to a trade-off between searching for food and avoiding competitors and predators (e.g., Brosse \& Lek, 2002). In recovery conditions selective segregation and habitat changes were probably the mechanism responsible for the spatial patterns among the species analyzed (e.g., Welker \& Scarnecchia, 2006). However, in critical low volume conditions the avoidance of interactive segregation and competition appears to be related to a different resource dimension (food and reproduction grounds). Examples include life-history variations which were related to differences in consumption for distinct predator size classes, and resource partitioning of the same food items such as the differential consumption of plankton prey taxa by the different Chirostoma species (Moncayo-Estrada et al., 2010) (Table 1).

The increasing impact from water-level fluctuations on shallow lakes, as long series of dry years occur more frequently, makes it increasingly important to understand the relationships between organisms and their environment. Our results show that overall trends in fish distribution can be assessed using different environmental variables and the species dominance. However, the finding of other pertinent variables must involve the analysis of a greater number of environmental variables and biotic factors such as abundance and distribution of preys. The analyses applied in this study potentially can help delineate conservation strategies in two critical aspects. First, by estimating relative abundance and effective fishing effort according to site and environmental characteristics preference by the species (e.g., Bigelow et al., 2002). Second, by defining a minimum critical volume of Lake Chapala to maintain biological integrity, principally, when the influence of the environmental variables has a greater effect on the species spatial patterns. This knowledge, in turn, will maximize stocking efficiency of Chirostoma in conservation programs trying to preserve fish diversity by implementing aquacultural initiatives as part of repopulation programs.

Although meteorological conditions have been described as the main driving factors affecting the lake volume change, some authors associated the declining water regime in the 1990's to the human use of water in the basin (de Anda \& Shear, 2001). Two closely related arguments support the role of human water use in reduced lake levels: (1) Despite an increase in rainfall the inflow value from the Rio Lerma dropped by more than half due to over exploitation upstream (inflow from 1922 to 1969 was 1,646 Mm3, and average annual rainfall was $706 \mathrm{~mm}$; inflow from 1970 to 2001 was $738 \mathrm{~mm}^{3}$ and average annual rainfall was $697 \mathrm{~mm}$; Aparicio, 2001). (2) Reduced inflow is associated with an increase in the hydraulic residence time, with a maximum value calculated in 1989 of 40 years and an average of 15 years for the last three decades- the average before the 1970 's was only five years (de Anda \& Shear, 2001). 
This study presents several possibilities for future research. First, an analysis including all species flock would validate whether or not there is a decisive influence from predators (large piscivorous Chirostoma species) on zooplanktivores distribution patterns. Second, a population dynamics study including not only the fish species but their preys in water-level fluctuations events (i.e. Sogard \& Olla, 1993; Lacroix \& Lescher-Moutoué, 1995; Jacobsen et al., 2004). Because zooplanktivore spatial patterns have been correlated to prey distribution and interference, the application of the analyses presented in this study have realistic potential to explain the population dynamics of preys.

\section{Acknowledgements}

Rodrigo Moncayo Estrada and Carlos Escalera Gallardo are supported by COFAA - Comisión de Operación y Fomento de Actividades Académicas - and EDI Estímulo al Desempeño Académico. We thank Jesus Morales, Rene Buelna, and Salvador Becerra for extremely helpful support in field and lab work and Frederick R. Gehlbach for critical review of the manuscript. The research upon which this paper is based was supported by SIMORELOS-CONACYT (19980306009), CEGEPI-IPN (970468), Bob Gardner Memorial Grant Award and Jack and Norma Folmar Endowment fund Research Award from Baylor University, and The Explorers Club Research Award.

\section{Literature Cited}

Anderson, M. J. 2001. Permutation tests for univariate or multivariate analysis of variance and regression. Canadian Journal of Fisheries and Aquatic Sciences, 58: 629-639.

Barbour, C. D. 1973. The systematics and evolution of the genus Chirostoma Swainson (Pisces: Atherinidae). Tulane Studies in Zoology and Botany, 18: 97-141.

Barbour, C. D. \& B. Chernoff. 1984. Comparative morphology and morphometrics of the pescados blancos (genus Chirostoma) from lake Chapala, Mexico. Pp. 111-127. In: Echelle A. A. \& I. Kornfeld (Eds.). Evolution of fish species flocks. University Maine at Orono Press, Maine, 385p.

Bigelow, K. A., J. Hampton \& N. Miyabe. 2002. Application of a habitat-based model to estimate effective longline fishing effort and relative abundance of Pacific bigeye tuna (Thunnus obesus). Fisheries Oceanography, 11: 143-155.

Blake, B. F. 1977. Lake Kainji, Nigeria: A summary of the changes within the fish population since the impoundment of the Niger in 1968. Hydrobiologia, 53: 131-137.

Blindow, I. 1992. Long- and short-term dynamics of submerged macrophytes in two shallow eutrophic lakes. Freshwater Biology, 28: 15-27.

Brind'amour, A., D. Boisclair, P. Legendre \& D. Borcard. 2005. Multiscale spatial distribution of a littoral fish community in relation to environmental variables. Limnology and Oceanography, 50: 465-479.

Brosse, S. \& S. Lek. 2002. Relationships between environmental characteristics and the density of age-0 eurasian perch Perca fluviatilis in the littoral zone of a lake: A nonlinear approach. Transactions of the American Fisheries Society, 131: 1033-1043.
Brosse, S., S. Lek \& F. Datiba. 1999. Predicting fish distribution in a mesotrophic lake by hydroacoustic survey and artificial neural networks. Limnology and Oceanography, 44: 1293-1303.

Brzeziecki, B. 1987. Analysis of vegetation-environment relationships using a simultaneous equations model. Vegetatio, 71: 175-184.

Castro, B. B., S. M. Marques \& F. Gonçalves. 2007. Habitat selection and dial distribution of the crustacean zooplankton from a shallow Mediterranean lake during the turbid and clear water phases. Freshwater Biology, 52: 421-433.

Chávez, E. A. 1973. Datos hidrobiológicos del lago de Chapala. Revista de la Sociedad Mexicana de Historia Natural, XXXIV: 125-146.

Cleveland, W. S. 1979. Robust locally-weighted regression and scatterplot smoothing. Journal of the American Statistical Association, 74: 829-836.

CNA (Comisión Nacional del Agua). 2006. Sistema de información geográfica del agua, Comisión Nacional del Agua. Subdirección General de Programación. CNA, México, 150p.

Connell, S. D. \& M. J. Kingsford. 1998. Spatial, temporal and habitat-related variation in the abundance of large predatory fish at One Tree Reef, Australia. Coral Reefs, 17: 49-57.

Coops, H., M. Beklioglu \& T. L. Crisman. 2003. The role of waterlevel fluctuations in shallow lake ecosystems - workshop conclusions. Hydrobiologia, 506: 23-27.

Fischer, P. \& U. Öhl. 2005. Effects of water-level fluctuations on the littoral benthic fish community in lakes: a mesocosm experiment. Behavioral Ecology, 16: 741-746.

Fukuhara, H., A. Kawakami \& T. Shimogaito. 2003. Characteristics of nutrient dynamics in Lake Sagate, Japan, a shallow sand dune lake. Hydrobiologia, 506: 93-99.

Gargett, A., J. Wells, A. E. Tejada-Martínez \& C. E. Grosch. 2004. Langmuir supercells: A mechanism for sediment resuspension and transport in shallow seas. Science, 306: 1925-1928.

Guisan, A., T. C. Edwards, Jr \& T. Hastie. 2002. Generalized linear and generalized additive models in studies of species distributions: setting the scene. Ecological Modelling, 157: 89-100.

Guzmán, A. M. 1995. La pesca en el lago de Chapala: Hacia su ordenamiento y explotación racional. Universidad de Guadalajara y Comisión Nacional del Agua, Mexico, City, 302p.

Guzmán, A. M. 2002. El lago de Chapala. Pp. 129-145. In: de la Lanza-Espino, G. \& J. L. García-Calderón (Eds.). Lagos y presas de México. Centro de Ecología y Desarrollo, A. C., Mexico City, 256p.

Hamrix, S. E. 1986. Vertical distribution and habitat partitioning between different size classes of Vendace (Coregonus albula), in thermally stratified lakes. Canadian Journal of Fisheries and Aquatic Sciences, 43: 1617-1625.

Hargeby, A., I. Blindow \& L. A. Hansson. 2004. Shifts between clear and turbid states in a shallow lake: multi-causal stress from climate, nutrients and biotic interactions. Archiv Für Hydrobiologie, 161: 433-454.

Hastie, T. J. 1992. Generalized additive models. Pp. 249-308. In: Chambers J. M. \& T. J. Hastie (Eds.). Statistical models in S. Wadsworth \& Brooks/Cole. Pacific Grove, California, 608p.

Hastie, T. J. \& R. Tibshirani. 1990. Generalized additive models. Chapman and Hall, London, 335p.

Hayes, J. W., M. J. Rutledge, B. L. Chisnall \& F. J. Ward. 1992. Effects of elevated turbidity on shallow lake fish communities. Environmental Biology of Fishes, 35: 149-168.

Hinch, S. G., N. C. Collins \& H. H. Harvey. 1991. Relative abundance of littoral zone fishes: biotic interactions, abiotic factors, and postglacial colonization. Ecology, 72: 1314-1324. 
Ita, E. O. 1978. An analysis of fish distribution in Kainji Lake, Nigeria. Hydrobiologia, 58: 233-244.

Jacobsen L., S. Berg, N. Jepsen \& C. Skov. 2004. Does roach behaviour differ between shallow lakes of different environmental state? Journal of Fish Biology, 65: 135-147.

Lacroix, G. \& F. Lescher-Moutoué. 1995. Spatial patterns of planktonic microcrustaceans in a small shallow lake. Hydrobiologia, 300-301: 205-217.

Legendre, P. \& M. J. Anderson. 1999. Distance-based redundancy analysis: Testing multispecies responses in multifactorial ecological experiments. Ecological Monographs, 69: 1-24.

Lepš, J. \& P. Šmilauer. 2003. Multivariate analysis of ecological data using CANOCO. Cambridge University Press, Oxford, 282 p.

Lévêque, C. 1997. Biodiversity dynamics and conservation: the freshwater fish of tropical Africa. Cambridge University Press, Oxford, 438p.

Lind, O. T. \& L. Dávalos-Lind. 1991. Association of turbidity and organic carbon with bacterial abundance and cell size in a large, turbid, tropical lake. Limnology and Oceanography, 36: 1200-1208.

Lind, O. T. \& L. Dávalos-Lind. 2002. Interaction of water quantity with water quality: the Lake Chapala example. Hydrobiologia, 467: 159-167.

Lyons, J., A. Gutíerrez-Hernández, E. Díaz-Pardo, E. Soto-Galera, M. Medina-Nava \& R. Pineda-López. 2000. Development of a preliminary index of biotic integrity (IBI) based on fish assemblages to assess ecosystem condition in the lakes of central Mexico. Hydrobiologia, 418: 57-72.

Magalhães, M. F., P. Beja, C. Canas \& M. J. Collares-Pereira. 2002. Functional heterogeneity of dry-season fish refugia across a Mediterranean catchment: The role of habitat and predation. Freshwater Biology, 47: 1919-1934.

Martínez-Pantoja, M. A., J. Alcocer \& A. M. Maeda-Martínez. 2002. On the Spinicaudata (Branchiopoda) from Lake Cuitzeo, Michoacan, Mexico: First report of a clam shrimp fishery. Hydrobiologia, 486: 207-213.

McArdle, B. H. \& M. J. Anderson. 2001. Fitting multivariate models to community data: A comment on distance-based redundancy analysis. Ecology, 82: 290-297.

McCune, B. \& M. J. Mefford. 2006. PC-ORD. Multivariate analysis of ecological data, Version 5.07. MjM Software Design. Glenedon Beach, Oregon.

McCune, B., R. Rosentreter, J. M. Ponzetti \& D. C. Shaw. 2000. Epiphyte habitats in an old conifer forest in western Washington, U.S.A. The Bryologist, 103: 417-427.

Meryem, B., S. Romo, I. Kagalou, X. Quintana \& E. Bécares. 2007. State of the art in the functioning of shallow Mediterranean lakes: workshop conclusions. Hydrobiologia, 584: 317-326.
Moncayo-Estrada, R. \& H. R. Buelna-Osben. 2001. Fish fauna of Lake Chapala. Pp. 215-242. In: Hansen, A. M. \& M. van Afferden (Eds.). The Lerma-Chapala watershed: evaluation and management. Kluwer Academic Press, New York, 385p.

Moncayo-Estrada, R., O.T. Lind \& C. Escalera-Gallardo. 2010. Trophic partitioning of sympatric zooplanktivorous silverside in a tropical shallow lake: Fish morphometry and diet composition. Copeia, 2010: 431-436.

Moncayo-Estrada, R., O. T. Lind \& C. Escalera-Gallardo. 2011. Trophic interactions among sympatric zooplanktivorous fish species in volume change conditions in a large, shallow, tropical lake. Neotropical Ichthyology, 9: 169-176.

Olden, J. D. \& D. A. Jackson. 2001. Fish-habitat relationships in lakes: Gaining predictive and explanatory insight by using artificial neural networks. Transactions of the American Fisheries Society, 130: 878-897.

Pouilly, M. \& M. A. Rodríguez. 2004. Determinism of fish assemblage structure in neotropical floodplain lakes: Influence of internal and landscape lake conditions. Pp. 243-265. In: R. Welcomme, R. \& T. Petr (Eds.). LARS2: Proceedings of the Second International Symposium on the Management of Large Rivers for Fisheries. FAO Publication 2004/17. FAO, Bangkok, 456p.

Sogard, S. M. \& B. L. Olla. 1993. The influence of predator presence on utilization of artificial seagrass habitats by juvenile walleye pollock, Theragra chalcogramma. Environmental Biology of Fishes, 37: 57-65.

Tejerina-Garro, F. L., R. Fortin \& M. A. Rodríguez. 1998. Fish community structure in relation to environmental variation in floodplain lakes of the Araguaia River, Amazon Basin. Environmental Biology of Fishes, 51: 399-410.

ter Braak, C. J. F. \& P. Šmilauer. 2002. CANOCO reference manual and CanoDraw for Windows user's guide - software for canonical community ordination, version 4.5. Microcomputer Power, New York, 500p.

U de G (Universidad de Guadalajara). 1983. Lago de Chapala: investigación actualizada. Instituto de Geografía y Estadística e Instituto de Astronomía y Meteorología. U de G, Guadalajara, $58 \mathrm{p}$.

Walters, C. L. \& S. J. D. Martell. 2004. Fisheries ecology and management. Princeton University Press, New Jersey, 399p.

Welker, T. L. \& D. L. Scarnecchia. 2006. River alteration and niche overlap among three native minnows (Cyprinidae) in the Missouri River hydrosystem. Journal of Fish Biology, 68: 1530-1545.

Wood, S. N. 2006. Generalized additive models, an introduction with R. Chapman \& Hall/CRC, Florida, 413p.

Submitted February 1, 2011 Accepted September 19, 2011 Published December 26, 2011 